\title{
Cultural tourism as a tool for urban regeneration in Istanbul
}

\author{
Ü. E. Uysal ${ }^{1} \&$ P. Özden ${ }^{2}$ \\ ${ }^{I}$ Department of Social Research, University of Helsinki, Finland \\ ${ }^{2}$ Department of Public Administration, Istanbul University, Turkey
}

\begin{abstract}
Over the last decades, cities have been acting as entrepreneurs in attracting visitors. They tend to develop marketing strategies to have a competitive advantage over the others. Cultural tourism, one of the main motivations behind these marketing strategies, has been widely adapted as an urban policy. This paper discusses how cultural tourism has become a tool for urban regeneration and how a sustainable and profitable cultural tourism can be compatible with urban regeneration policies in Istanbul. This study also evaluates Istanbul 2010: The European Capital of Culture, which has been one of the agenda topics in the last few years. Thus, we regard the European Capital of Culture event as a stage to present developments in cultural tourism and its effects on urban regeneration. Keywords: cultural tourism, urban regeneration, Istanbul, European capital of culture.
\end{abstract}

\section{Introduction}

Cultural tourism has been one of the prominent strategies of cities to generate new sources of income. Cultural tourism, an important tool for the expansion of cultural facilities, is also assumed to contribute urban economy and urban growth. Tourism strategies often cause physical changes in the built environment. The close relationship between cultural tourism and culture led urban regeneration has been one of the delicate topics that aroused academic interest. In this paper, we discuss the main patterns of this relationship and evaluate dynamics of culture led urban regeneration in the case of Istanbul. First, we will introduce the mutual relationship between cultural tourism and urban regeneration. Then we will discuss Istanbul's recent development as a tourist city. In the following, we analyze urban regeneration in Istanbul in consideration 
of European Capital of Culture (ECOC) in 2010. Lastly we will critically evaluate the outcomes of culture led urban regeneration in Istanbul and explore how a sustainable and profitable cultural tourism can be compatible with urban regeneration policies.

\section{Cultural tourism and urban regeneration}

\subsection{Conceptual expansion}

In the late 1970s and the early 1980s, globalization and structural adjustment policies and new cultural dynamics have triggered "urban cultural policies" (Bianchini [1]). Culture's role in urban development strategies has been consolidated due to competition of cities on a global scale to attract visitors and investment. In this context, culture has been increasingly a prominent part of tourism with the rising interest in heritage, art, culture, history and contemporary lifestyle (Williams [2]). Cities, which are still centres of "cultural industries", seek to market their assets to secure a crucial position in the map of globally competing cities (Russo and Borg [3]). Because cultural tourists are likely to stay more nights and spend more [4] cultural tourism has become significant in cities' tourism strategies. The World Tourism Organization confirms that $37 \%$ of international travels are culture motivated [5].

Expectations from cultural tourism often go beyond short term benefits that cities seek long lasting and sustainable changes in the built environment and adapt culture led urban regeneration as an urban policy. In the long run, culture led urban regeneration is assumed to contribute urban economy, conservation and promotion of urban heritage, redevelopment of city centres, revival of former industrial zones and waterfront sites (Evans [6], Binns [7]). Culture led urban regeneration is also considered as a tool to protect and promote urban cultural diversity (Garcia [8]). Similarly, Shaw et al. [9] emphasize that cultural tourism adds value to the area by promoting the existing ethnic and cultural identity cultural tourism's role in promoting urban ethnic and cultural identities.

It is assumed that investing in culture will make the city more and more attractive which will increase the number of visitors and tourism revenue. However, this circle does not necessarily work well. Although culture led urban regeneration rhetoric often considers well being of citizens, greater participation and democracy (Evans [6]) revitalization of cultural life (Miles and Paddison [10]) empowerment of local communities, it may lead poverty, unemployment, gentrification, eviction and displacement (Evans [6], Binns [7]) denial of local identity (Miles and Paddison [10]) and even limited economic recovery of the area (Evans [11]). Previous studies on culture led regeneration consider four interrelated elements: urban branding, flagship projects, hallmark events and the creative milieu.

\subsection{Urban branding}

According to Kavaratzis and Ashworth [12-14], cities have to differentiate themselves from each other to market their assets which largely depend on the 
city's image. This image can be turned into an urban brand with a simple and catchy slogan and memorable, well-designed logo. Occasionally urban regeneration and branding strategies have close ties with city marketing (Paddison [15]). They may feed each other that "cultural projects give emotional 'fuel' for successful destination brands and cultural brands can be adopted by commercial regeneration projects" (Tibbot [16]).

\subsection{Flagship projects}

Culture led regeneration aims to "bring life" to cities with "hard cultural infrastructure" (Binns [7]) including building cultural centres like museums, art galleries, theatres etc. Such infrastructure sometimes includes construction of costly iconic buildings and symbol landmarks (i.e. Guggenheim Museum, Baltic Four Mills, Kiasma, Kunsthaus etc.) which are used in city marketing. In addition, investing in cultural infrastructures play a considerable role in future visions of cities (Dündar [17]). It is also assumed that investing in culture contributes socio-economic and physical sustainability to the area.

\subsection{Hallmark events}

In the global map of competition, cities seek to host international events to attract visitors and investment. Hallmark events not only contribute the image of a particular city and boost local pride, but also become a catalyst for urban regeneration (Binns [7], Garcia [8]). Particularly Olympics and ECOC play important roles to change built environment and encourage cultural tourism. Hallmark events generate considerable income, though in some cases they can cause big financial losses. Thus, hallmark events could be for the benefit of the inhabitants or they can result in political, social or environmental damage (Hall [18]).

\subsection{The creative milieu}

According to Florida [19] human capital is the key to urban economic growth and 'successful' urban regeneration. Due to the confidence that creative milieu in cultural industries brings economic development; Florida's narrative has become increasingly popular. Cities tend to support cultural infrastructures to attract 'creative' human capital (Garcia [8]). His overemphasis on clustering human capital and overgeneralization of creativity has received numerous critics.

\section{Cultural tourism and urban regeneration in Istanbul}

\subsection{Istanbul: a rising tourist city}

Since the 1980s, tourism industry in Turkey benefited from financial priorities, incentives and subsidy; public lands rented by entrepreneurs with favourable terms (Aykaç [20]). The Tourism Encouragement Law in 1982, introducing new incentives to the private sector provided a legal basis for subsidy for the 
development of tourist facilities (Kocabaş [21], Yüksel et al. [22]). The law had considerable affects on Istanbul's tourism agenda and paved the way for particular districts to develop as tourism zones. Consequently Turkey has become a "tourism country" since the late 1980s (Urry [23]).

In 2009, Turkey is ranked the 7th on the list of the most visited countries with about 27 million tourists $[4,24]$ (see figure 1). Istanbul is ranked as the $9^{\text {th }}$ on the list of the most visited cities in the world, with more than 7.5 million international visitors [25] (see figure 2). Istanbul also enjoyed the fastest growth in top ten destinations (see table 1).

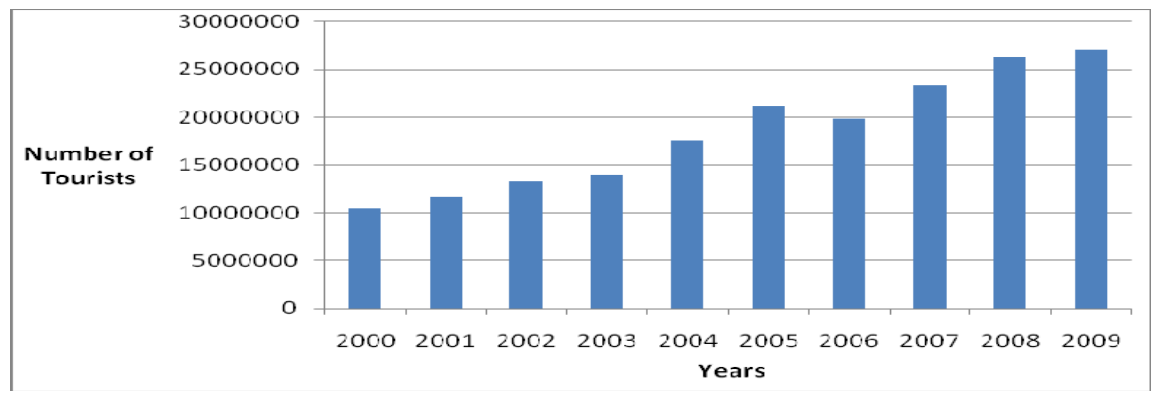

Figure 1: Number of tourists in Turkey 2000-2009 [24].

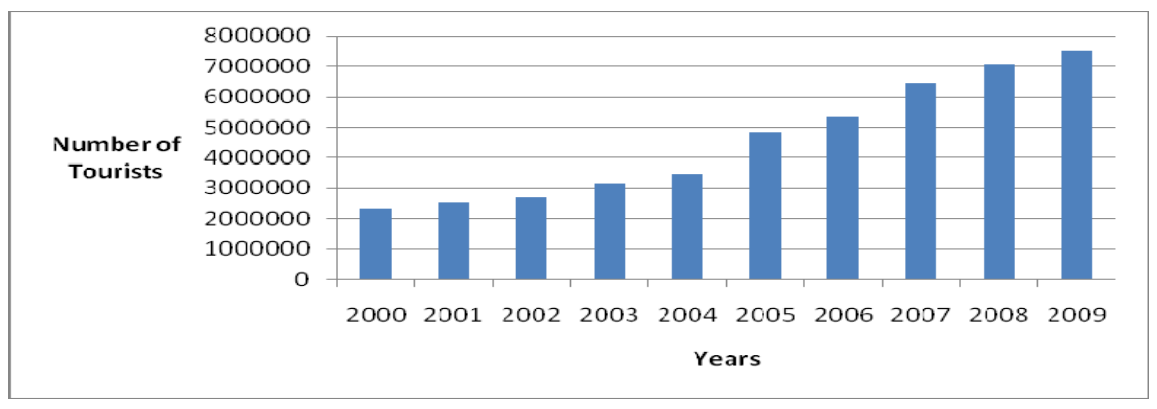

Figure 2: $\quad$ Number of tourists in Istanbul 2000-2009 [24].

Istanbul has improved its tourism facilities for hospitality management in the last five years (see table 2). The number of international events has doubled in the last ten years and the number of participants exceeded 75.000 (see table 3). In terms of congress participants, Istanbul is ranked as the $4^{\text {th }}$ in the world in 2009 [26].

In 2013, it is assumed that Turkey will host over 40 million tourists with $\$ 1000$ spending per tourist and receive approximately $\$ 50$ billion tourism income [28]. Although Istanbul's bed capacity is considerably better than its competitors (i.e. 4 times more than Lisbon, 2 times more than Barcelona), average length of stay has decreased from 4 to 2.4 days in the last two decades. Clearly, Istanbul has become a transfer point to for foreign visitors. 
Table 1: $\quad$ Top city destination ranking [25].

\begin{tabular}{|c|c|c|c|}
\hline City & Rank & $\begin{array}{c}\text { Arrivals 2009, } \\
\mathbf{0 0 0 0}\end{array}$ & $\begin{array}{c}\mathbf{\%} \text { growth } \\
\mathbf{2 0 0 8} / \mathbf{2 0 0 8}\end{array}$ \\
\hline London & 1 & 14,059 & -4.7 \\
\hline Bangkok & 2 & 9,986 & -2.2 \\
\hline Singapore & 3 & 9,683 & -4.3 \\
\hline Kuala Lumpur & 4 & 9,400 & 5.2 \\
\hline Antalya & 5 & 8,868 & 3.5 \\
\hline New York City & 6 & 8,479 & -10.7 \\
\hline Dubai & 7 & 7,783 & 2.6 \\
\hline Paris & 8 & 7,750 & -6.9 \\
\hline Istanbul & 9 & 7,543 & 7 \\
\hline Hong Kong & 10 & 7,011 & -3.8 \\
\hline
\end{tabular}

Table 2: $\quad$ Development of tourism facilities 2007-2010 [27].

\begin{tabular}{|c|c|c|c|}
\hline Year & $\begin{array}{c}\text { Number of } \\
\text { Facilities }\end{array}$ & $\begin{array}{c}\text { Number of } \\
\text { Rooms }\end{array}$ & $\begin{array}{c}\text { Number of } \\
\text { Beds }\end{array}$ \\
\hline 2007 & 842 & 49,529 & 98,999 \\
\hline 2008 & 1,077 & 54,399 & 108,506 \\
\hline 2009 & 1,134 & 53,541 & 106,191 \\
\hline 2010 & 1,235 & 69,762 & 139,949 \\
\hline
\end{tabular}

Table 3: Development of congress tourism in Istanbul 2000-2009 [26].

\begin{tabular}{|c|c|c|}
\hline Year & $\begin{array}{c}\text { Number of International } \\
\text { Events }\end{array}$ & $\begin{array}{c}\text { Number of } \\
\text { Participants }\end{array}$ \\
\hline 2000 & 29 & 17,888 \\
\hline 2001 & 35 & 46,806 \\
\hline 2002 & 35 & 26,365 \\
\hline 2003 & 47 & 42,631 \\
\hline 2004 & 52 & 31,655 \\
\hline 2005 & 59 & 47,121 \\
\hline 2006 & 76 & 44,547 \\
\hline 2007 & 79 & 30,536 \\
\hline 2008 & 82 & 56,179 \\
\hline 2009 & 80 & 75,768 \\
\hline
\end{tabular}

\subsection{Cultural tourism as a tool for urban regeneration in Istanbul}

Urban regeneration in Turkey is a recent phenomenon. It can be traced back to the 1980s. Aftermath a few regeneration projects in Ankara, urban regeneration has been adapted as an urban policy in the early 2000s. Unlike its counterparts in 
Europe and North America, urban regeneration in Istanbul did not aim to redevelop city centres in the post war period or to revitalize city centres which were abandoned due to urban sprawl. Instead, urban regeneration policies in Istanbul have been motivated by the Marmara Earthquake (1999), informal housing, increase in international investment, Turkey's EU candidacy and adaptation process to the EU policies. Over the last two decades, urban regeneration's local features, methods and local governments' role have been discussed and redefined (Özden [29]). Consecutively made regulations have been legal basis for urban regeneration. The new law in 2005 separated urban renewal and regeneration. It limited conditions for urban renewal only in registered areas. Urban regeneration, which initially began in residential areas and waterfronts, has recently been discussed as a tool for cultural tourism as Istanbul bears the title of ECOC (Özden [30]).

Cultural tourism oriented regeneration projects in Istanbul are recently included on government agendas. Today, development of cultural tourism strategies is the main objective for several regeneration projects, primarily set for registered residential zones, tourism areas and waterfronts. Intangible heritage, one of the main tools to bring cultural motifs to tourism, has a significant role in culture led urban regeneration. Turkey signed The Convention for the Safeguarding of the Intangible Cultural Heritage, prepared by UNESCO in 2003. In the convention, the intangible cultural heritage is defined as "the practices, representations, expressions, knowledge, skills as well as the instruments, objects, artefacts and cultural spaces associated therewith" [31]. The convention recognizes that "communities, in particular indigenous groups and in some cases, individuals, play an important role in the production, safeguarding, maintenance and recreation of the intangible cultural heritage, thus helping to enrich cultural diversity and human creativity" [31]. Nevertheless, current regeneration projects ignored intangible cultural heritage. Previous implementations only adopted strategies to "consume places". In the last five years urban regeneration projects were implemented in several districts like Küçükçekmece, Halkalı, Çatalca, Zeytinburnu, Esenler, Esenyurt, Maltepe, Güngören, Başakşehir, Ataşehir, Kartal, Gaziosmanpaşa-Sarıöl, Fatih-Sulukule, Fener-Balat, Müze-kent, Topkapı industrial zone, Eminönü-Hanlar Area, Ayvansaray, Yenikapı-Yalı Neighbourhood, Süleymaniye and BeyoğluTarlabaşı-Galata-Tophane. Among these, particularly the Tarlabaşı Urban Regeneration Project and the Sulukule Urban Regeneration Project were criticized for ignoring cultural aspects for tourism development.

The Istanbul Environmental Plan 2009 considers both banks of the Golden Horn, The Historical Peninsula, Sütlüce and Tophane as cultural tourism districts (see figure 3). The change in the banks of the Golden Horn has begun with the transformation of former industrial plants and waterfronts into cultural places. Recently opened art galleries, thematic museums, culture and conventional centres indicate the drastic change in the area (see figure 4). Flagship projects like Santral Istanbul, Kadir Has University, Feshane, Sütlüce Congress Centre, Miniatürk, The Rahmi Koç Museum, and Istanbul Modern have contributed in transformation and emerged as attractive locations for cultural tourism. 


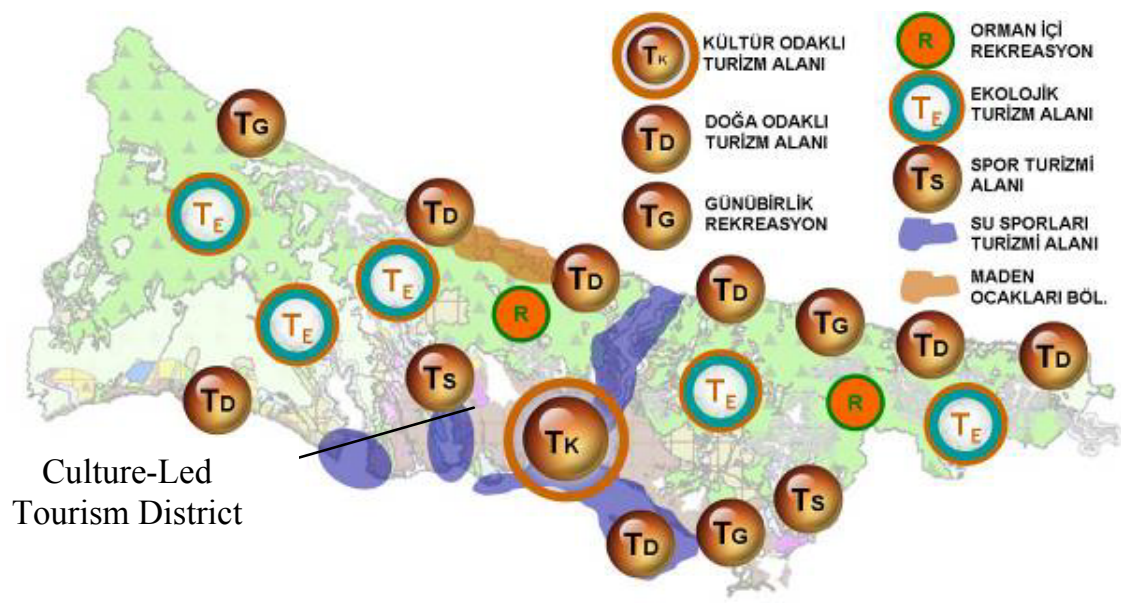

Figure 3: Function centers of Istanbul [32].
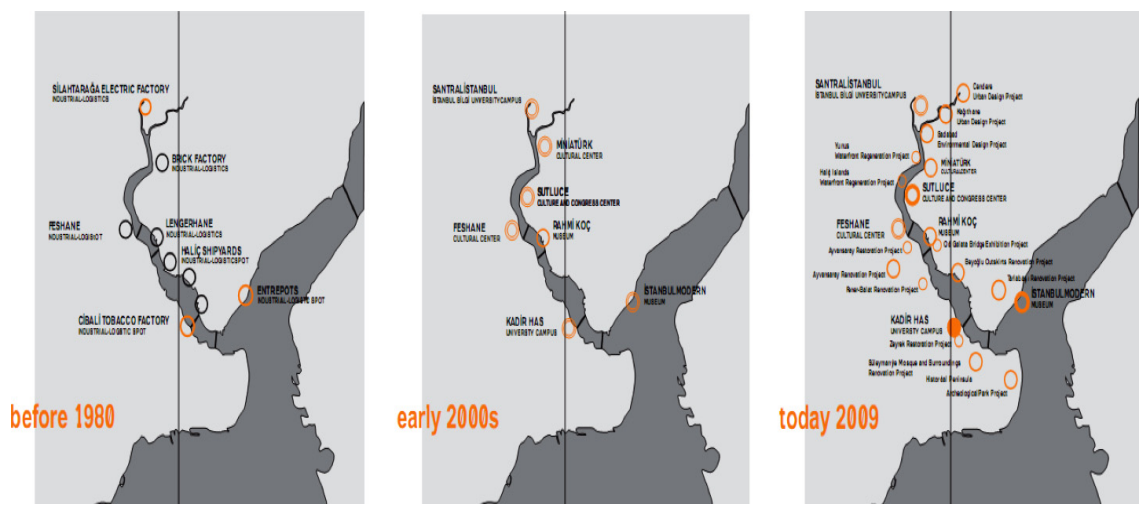

Figure 4: Cultural tourism led urban regeneration in Istanbul 1980-2009 [33].

The Istanbul Metropolitan Planning and Urban Design Centre unit, which is responsible for preparing the Istanbul Environmental Plan, recommends that Istanbul's tourism potential should be reconsidered in accordance with those changes in the cityscape [5]. The unit urges that "cultural heritage, museums, culture and art festivals and congress tourism are not only crucial to promote Istanbul on the global scale but also equally significant for a live and vivid urban cultural life [5]. In this context, both The Historical Peninsula and the Golden Horn have been focuses of cultural tourism and urban regeneration. Turgut and Özden [34] particularly regards The Historical Peninsula as "showcase of the city" and cultural tourism led regeneration is inevitable for this area, which has always been suggested in Conservation Plans. According to Turgut and Özden [34] tourism will contribute the growth and stabilisation of region's internal economy. 


\subsection{Istanbul 2010 the European capital of culture}

The European Cities of Culture, the bases of which were laid in 1985 was named as the European Capital of Culture in 1999. On 11 March 2006, Essen from Germany, Pécs from Hungary and Istanbul from Turkey were selected as European Capitals of Culture for 2010 by the EU Council. Since 1985, more than 30 cities have been designated ECOC. Following this decision, The Istanbul 2010 European Capital of Culture Agency was established in 2007. The Istanbul 2010 European Capital of Culture Agency is responsible for planning all exhibitions, concerts, conferences, urban projects and tourism activities with cultural and social content, to make recommendations to the institutions and organizations about urban regeneration agenda, to provide coordination between public institutions, trade associations, NGOs and volunteers. Further, the agency is in charge of preparing projects for maintenance, repair and restoration of immovable cultural assets and making recommendations on construction of new culture and art centres. The Istanbul 2010 European Capital of Culture Agency's aims cover a wide scope of activities, some of which directly refer cultural tourism as a catalyst for urban regeneration. For example, the agency introduces typical and abstract objectives like promoting Istanbul's unique urban identity with art and cultural activities, increasing Istanbul's share in cultural tourism market, integrating with the European cultural sphere, encouraging Istanbulites to participate in decision making. In addition, some objectives like implementing projects for conservation of the cultural heritage, developing cultural infrastructure, building new cultural and art places, increasing the quality of life in Istanbul are related to culture led urban regeneration [35]. Consequently, ECOC in 2010 has initiated a remarkable change in the built environment. Besides numerous of daily cultural activities and festivities, several projects were implemented to make permanent changes in Istanbul's cultural scene. For example, two new museums (Museum of Prince Islands and The Mimar Sinan Research Centre Museum) were built. Vortvots Vorodman Armenian Church and Otağ-1 Hümayun (The Sultan's Garrison Quarters) have been restored and transformed into cultural centres. Restorations in Prince Imaret, Hagia Sophia and Topkapi Palace and project works in Kariye Museum are other remarkable urban projects in 2010 .

Approximately $60 \%$ of the agency's budget was spent on restoration projects (see table 4). About 50 million liras (out of 250 million liras budget for the agency) was spent for the conservation of World Heritage. With the agreement in 2009, the agency provides funding for the Field Management on Historical Peninsula Unit. In this restructuring process, Evans [36] states the necessity to increase the number of "attractive" locations for cultural tourism. In summary, Istanbul 2010 ECOC has been a significant opportunity to implement culture led urban regeneration projects which will contribute cultural tourism in the long run. 
Table 4: The Istanbul 2010 European capital of culture agency's budget [35].

\begin{tabular}{|c|c|c|c|}
\hline & $\begin{array}{c}\text { Expected } \\
\text { Income (TL) }\end{array}$ & $\begin{array}{c}\text { Real Income } \\
(\mathrm{TL})\end{array}$ & $\begin{array}{c}\text { Spent on } \\
\text { Projects }\end{array}$ \\
\hline 2008 & $240,273,000$ & $78,487,387$ & $10,755,410$ \\
\hline 2009 & $805,156,000$ & $260,230,546$ & $27,201,383$ \\
\hline 2010 & $303,200,000$ & $224,983,685$ & $126,725,629$ \\
\hline 2011 & $178,761,664$ & (until March) & $35,268,694$ \\
$\begin{array}{c}\text { (Until } \\
\text { June) }\end{array}$ & & $13,603,244$ & \\
\hline
\end{tabular}

\section{Conclusion and assessment}

Due to limited evidential basis, measuring long term social, economic and environmental impacts of urban regeneration has always been problematic (Evans [6], Miles and Paddison [10]). It is similarly difficult to define what a 'successful' urban regeneration is. For instance, it is also hard to state how culture led urban regeneration has contributed urban economy in the short run. On the other hand, in the context of ECOC 2010 Istanbul, it is relatively less difficult to evaluate the outcomes of culture led urban regeneration. Considering expectations and remarkable consequences may give us a clue.

Positive Outcomes: At the first glance, ECOC was a great opportunity for Istanbul to reclaim its historical and cultural assets. New cultural centres, museums and art galleries were opened. The Istanbul 2010 European Capital of Culture Agency organized hundreds of activities which revitalized culture and art scene in Istanbul. The agency, a combination of private-public partnerships, nongovernmental organizations, professionals and academic units, employed several projects to encourage citizen participation and promote city identity. Finally, the most remarkable success is the restoration of particular churches and mosques, which are valuable assets of Istanbul's cityscape.

Negative Outcomes: What we also see in the Istanbul case are general concerns about culture led urban regeneration. Miles and Paddison [10] ask "what do such developments actually mean in terms of the lives of those people who live in that city?" to question regeneration narratives. Social inclusion, one of the primary goals set for culture led urban regeneration, is often determined by an individual or by social groups according to their "relationship to marketplace" and their roles as "customers"; urban regeneration often underestimates the value of culture for the people of a locality (Miles and Paddison [10]). The Sulukule case, a Romany neighbourhood in the very centre of Istanbul, shows how urban regeneration disregards local culture. In the year of ECOC, urban regeneration caused a complete destruction of an ethic and cultural enclave where Romany residents were evicted, displaced and faced unemployment, poverty and homelessness Özden [30]. Urban regeneration 
projects disregarded social and cultural needs of the locals and denied cultural diversity in the expense of the" legitimate culture".

Suggestions: According to Russo and Borg [3] tourism developments bring further expenditures in the long run. Therefore, cultural tourism policies require a balanced utilisation. In the Istanbul case, ECOC has been a significant experience in developing a cultural tourism agenda. We suggest that urban regeneration projects should consider social, cultural and environmental sustainability. In this context, Bailey et al. [37] stress one crucial issue that "we should avoid any temptation to generalize interests of culture led urban regeneration...successful examples of culture led urban regeneration do in fact engage with a pre-existing collective sense of local identity". In the Istanbul case, we also believe that promoting multi-cultural, ethnic and religious diversity shall hinder negative outcomes of urban regeneration. In achieving sustainable cultural tourism and promoting Istanbul's unique neighbourhoods, culture led urban regeneration projects should also consider intangible assets (i.e. local (sub) cultures) and rehabilitation of locals' socio-economic and cultural conditions rather than only transforming physical space.

\section{References}

[1] Bianchini, F., Remaking European Cities: The Role of Cultural Policies, in F. Bianchini \& M. Parkinson (eds) Cultural Policy and Regeneration: The West European Experience, Manchester: Manchester University Press, pp. 1-20, 1993

[2] Williams, P. Cultural Tourism and the UK City of Culture, 2010 $\mathrm{http}: / / \mathrm{www}$.insights.org.uk/articleitem.aspx?title $=$ Cultural + Tourism + and $+\mathrm{t}$ he + UK + City + of + Culture

[3] Russo, A. P. \& Borg, J., Planning considerations for cultural tourism: a case study of four European cities, Tourism Management 23, pp. 631-637, 2002

[4] World Tourism Organization Tourism Highlights, $2010 \mathrm{http}: / /$ unwto.org/en

[5] İstanbul Çevre Düzeni Planı, Kültür Endüstrileri- Kültür ve Turizm AltGrubu Raporu, İstanbul Metropolitan Planlama ve Kentsel Tasarım Merkezi, 2009

[6] Evans, G., Measure for Measure: Evaluating the Evidence of Culture's Contribution to Regeneration, Urban Studies, 42(5/6), pp. 950,983, 2005

[7] Binns, L., Capitalising on culture: an evaluation of culture-led urban regeneration policy, Futures Academy, Dublin Institute of Technology, 2005

[8] García, B., Cultural Policy in European Cities: Lessons from Experience, Prospects for the Future in: Special edition on Cultural Policy and Regeneration, Local Economy, 19(4), pp. 312-326, 2004

[9] Shaw S, Bagwell S, \& Karmowska J., Ethnoscapes as Spectacle: Reimaging Multicultural Districts as New Destinations for Leisure and Tourism Consumption, Urban Studies, 41(10), pp.1983-2000, 2004

[10] Miles, S. \& Paddison, R., Introduction: The Rise and Rise of Culture-led Urban Regeneration, Urban Studies, 42( 5/6), pp.833-839, 2005 
[11] Evans, G., Hard-branding the Cultural City From Prado to Prada, International Journal of Urban and Regional Research, 27(2), pp.417-440, 2003

[12] Kavaratzis, M. \& Ashworth, G. J., City Branding: An Affective Assertion of Identity or a Transitory Marketing Trick? Tijdschrift voor Economische en Sociale Geografie 96(5), pp.506-514,2004

[13] Kavaratzis, M. \& Ashworth, G. J., Partners in Coffeeshops, Canals and Commerce: Marketing the City of Amsterdam, Cities, 25(1), pp.16-25, 2007

[14] Kavaratzis, M. \& Ashworth, G. J., Beyond the Logo: Brand management for cities, Brand Management, 16(8), pp.520-531, 2009

[15] Paddison, R., City Marketing, Image Reconstruction and Urban Regeneration, Urban Studies, 30(2), pp.339-349, 1993

[16] Tibbot, R., Culture club: can culture lead urban regeneration? Locum Destination Review 9 Autumn. pp.71-73, 2002

[17] Dündar G., S., Nitelikli Yapılaşma “Geleceğin İzmir'inde Kentsel Mekânın Kültürel Niteliği, İzmir Kent Sempozyumu, pp. 467-481, 2009

[18] Hall, C.M., Hallmark Tourist Events: Impacts, Management and Planning, Belhaven Press: London 1992,

[19] Florida, R. The Rise of the Creative Class: And How It's Transforming Work, Leisure, Community and Everyday Life, Basic Book: New York, 2002

[20] Aykaç, A. Yeni Işsler, Yeni Iş̧̧̧iler: Turizm Sektöründe Emek [Labor in Tourism Sector] İletişim Yayınları: Istanbul, 2009

[21] Kocabaş, A., Urban Conservation in Istanbul: Evaluation and Reconceptualization, Habitat International 30, pp.107-126, 2006

[22] Yüksel F., Bramwell, B. \& Yüksel A., Centralized and Decentralized Tourism Governance in Turkey, Annals of Tourism Research, 32(4), pp.859-886, 2005

[23] Urry, J., The Tourist Gaze: Leisure and Travel in Contemporary Societies, Sage: London, 1993

[24] Turkish Statistical Institute, the official website http://www.tuik.gov.tr/

[25] Euromonitor International http://www.euromonitor.com/

[26] International Congress and Convention Association http://www.iccaworld.com

[27] Directorate of Culture and Tourism of Istanbul http://www.istanbulkulturturizm.gov.tr/

[28] Türkiye Turizm Stratejisi Eylem Planı (TTSER) 2007-2013, Kültür ve Turizm Bakanlığı, 2007, Ankara

[29] Özden P. P., Kentsel Yenileme Uygulamalarında Yerel Yönetimlerin Rolü Üzerine Düşünceler ve İstanbul Örneği, $I \ddot{U}$. SBF. Der., 23-24, pp. 255-269 Ekim 2000-Mart 2001

[30] Özden P. P., Sulukule: An Opportunity Missed In The Tourism-Led Regeneration, Sustainable Tourism III, (eds: F.D. Pıneda, C.A. Brebbia), WIT Press: Boston, pp.141-152 2008 
[31] UNESCO, The Convention for the Safeguarding of the Intangible Cultural Heritage, 2003 http://www.unesco.org/culture/ich/doc/src/01852-EN.pdf

[32] İBB. 1/100.000 ölçekli İstanbul Çevre Düzeni Planı Raporu, 2009.

[33] http://mutlukent.wordpress.com/2010/09/23/tophane-2010/

[34] Özden, P.P., Turgut, S., Towards A Sustainable and Tourism-Led Urban Regeneration Objective: Eminonu Historical City Core, Sustainable Development and Planning II, 2005, Vol. 1, (eds) Kungolos A.G., Brebbia C.A., Beriatos E., WIT Press: Southampton, Boston, pp.171-180, 2005

[35] The Istanbul 2010 European Capital of Culture Agency http://www.istanbul2010.org

[36] Evans G., Panel Konuşması, Beyoğlu'nu Yeniden Düşünmek Ve Düşlemek-1", Kültür Ve Turizm Eksenli Yeniden Canlandırma Stratejileri Paneli, İstanbul, 2007

[37] Bailey, C., Miles, S. \& Stark, P., Culture-led Urban Regeneration and the Revitalisation of the Identities in Newcastle, Gateshead and the North East of England, International Journal of Cultural Policy, 10(1), pp. 47-65, 2004 